\title{
Effects of Teucrium polium L. (Lamiaceae) essential oil and $\alpha$-pinene on the detoxifying- and intermediary engaged enzymes of Ephestia kuehniella Zeller, 1879 (Lep.: Pyralidae)
}

\author{
Morteza SHAHRIARI ${ }^{1}$, Najmeh SAHEBZADEH ${ }^{1,2}$, Arash ZIBAEE ${ }^{3}$
}

Received October 28, 2018; accepted May 10, 2019.

Delo je prispelo 28. oktobra 2018, sprejeto 10. maja 2019.

Effects of Teucrium polium L. (Lamiaceae) essential oil and $\alpha$-pinene on the detoxifying- and intermediary engaged enzymes of Ephestia kuehniella Zeller, 1879 (Lep.: Pyralidae)

Abstract: This study investigated the effect of Teucrium polium L. essential oil (Tp EO) and $\alpha$-pinene as its major component on the detoxifying- and intermediary-engaged enzymes of Ephestia kuehniella Zeller. Fourth instar larvae were separately fed on the treated artificial diets incorporated with $\mathrm{LC}_{50}$ concentration of Tp EO $\left(4.91 \mu \mathrm{lml}^{-1}\right)$ and $\alpha$-pinene (10.66 $\left.\mu \mathrm{l} \mathrm{m} \mathrm{m}^{-1}\right)$. After three time intervals $(24,48,72$ hours), larval hemolymph was extracted to determine enzymatic activities. Activity of esterase, alanine and aspartate aminotransferases, aldolase, lactate dehydrogenase, and alkaline phosphatase were decreased in the treatments compared with the control. No significant differences were observed between some enzymes in the treated larvae highlighting their ineffectively role to detoxify and to metabolize Tp EO and a-pinene in the hemolyph of E. kuehniella larvae.

Key words: Teucrium polium L.; flour moth; essential oil; detoxifying enzymes; phenoloxidase; toxicity; physiological response
Učinki eteričnih olj in a-pinena iz istrskega vrednika ( $T e$ ucrium polium L.) na razstrupljevanje in aktivnosti pri tem sodelujočih encimov močne vešče (Ephestia kuehniella Zeller, 1879, Lepidoptera: Pyralidae)

Izvleček: $\mathrm{V}$ raziskavi so bili preučevani učinki eteričnih olj in a-pinena kot njihove glavne sestavine iz istrskega vrednika (Teucrium polium L., Tp EO) na njihovo razstrupljanje in aktivnosti pri tem udeleženih encimv močne vešče (Ephestia kuehniella Zeller, 1879). Ličinke četrtega štadija so bile hranjene $\mathrm{z}$ umetnimi pripravki, ki so vsebovali $\mathrm{LC}_{50}$ koncentracijo Tp EO $\left(4,91 \mu \mathrm{l} \mathrm{ml}^{-1}\right)$ in $\alpha$-pinena $\left(10,66 \mu \mathrm{l} \mathrm{ml}^{-1}\right)$. Po treh časovnih presledkih $(24,48,72$ ur) je bila za določanje encimske aktivnosti ekstrahirana hemolimfa ličink. Aktivnosti esteraze, alanin in aspartat aminotransferaz, aldolaze, laktat dehidrogenaze in alkalne fofataze so se zmanjšale po obravnavanjih v primerjavi s kontrolo. Pri tretiranih larvah ni bilo značilnih razlik med posameznimi encimi, kar kaže na neučinkovitost fiziologije močne vešče pri tretiranju s Tp EO ali z $\alpha$-pinenom.

Ključne besede: Teucrium polium L.; močna vešča; eterična olja; detoksifikacijski encimi; fenoloksidaza; toksičnost; fiziološki odziv

1 University of Zabol, Faculty of Agriculture, Department of Plant Protection, Zabol, Iran

2 Corresponding author, e-mail: n.sahebzadeh@uoz.ac.ir

3 University, of Guilan, Faculty of Agricultural Sciences, Department of Plant Protection, Rasht, Iran 


\section{INTRODUCTION}

One of the most effective ways to supply human food is proper storage of agricultural products in order to prevent them being wasted after harvest on farm. One of the main problems in preserving stored foods is the presence of insect pests, which cause qualitative and quantitative damages on stored products. Polyphagy, widespread distribution and reproductive ability of these pests are the causes of their significant damage (Rajendran \& Sriranjini, 2008). Therefore, the importance of using pesticides in warehouses has become inevitable to protect storage products. In the recent years, control of stored product pests is commonly done by chemical gas pesticides, whose uncontrolled use of these compounds causes problems such as residues of toxins in food and the emergence of resistant populations (Negahban et al., 2007; Rajendran \& Sriranjini, 2008). The existence of such problems has led researchers to seek alternative and less hazardous methods such as diatomaceous earth and powders of plants to efficient and safe control of stored product pest (Bohinc et al., 2013, 2018). The secondary metabolites of plants can partly be the alternatives of synthetic pesticides because of some features such as rapid decomposition, reduction of environmental pollution, wider range of effects and suitability for small scale applications, especially storage facilities, (Rajendran \& Sriranjini, 2008; Yang et al., 2014). The toxicological effects of plant compounds on insects is diverse as vegetable oils, alkaloids and monoterpenoids negatively affects fecundity, egg-laying, repellency and development of insects (Isman, 2006; Bouayad et al., 2012; Kumrungsee et al., 2014). These compounds also disrupt intermediary metabolism and reduce the ability of the immune system against pathogenic agents (Zibaee \& Bandani, 2010b; Shahriari et al., 2017b).

Teucrium polium L. is a perennial herb in the Lamiaceae family which is native to Mediterranean regions, Middle East, Europe and North Africa. A major component of Teucrium polium essential oil (Tp EO) is a-pinene having the potential antimicrobial, antifungal and antioxidative properties (Tariq et al., 1989; Moghtader, 2009; Sharififar et al., 2009; Darabpour et al., 2010). Tp EO and a-pinene have shown different effects on biology and physiology of insects via fumigant, contact and oral toxicities against Callosobruchus maculatus (Fabricius, 1775), Col.: Chrysomelidae), Tribolium castaneum (Herbest, 1797, Col.: Tenebrionidae), Sitophilus oryzae (Linnaeus, 1763, Col.: Curculionidae) and Ephestia kuehniella (Lep.: Pyralidae) (Heydarzade \& Moravvej, 2012; Shahriari et al., 2016; Shahriari et al., 2017). Also those have been proved to inhibit acetylcholinesterase (AChE) of Reticulitermes speratus (Kolbe, 1885), Isoptera: Rhinotermiti- dae) after treating by a-pinene (Seo et al., 2014). In our previous study, survival, digestion and energy reserves of E. kuehniella larvae were determined after Tp EO and a-pinene treatments (Shahriari et al., 2017b) while in the current study, we aimed to find the possible effects of $T p$ $\mathrm{EO}$ and $\alpha$-pinene on detoxifying- and intermediary-engaged enzymes in E. kuehniella larvae.

\section{MATERIALS AND METHODS}

\subsection{ESSENTIAL OIL AND A-PINENE PREPARA- TION}

The aerial parts of T. polium were collected from different locations in Sistan and Baluchestan Province of Iran (Zabol: $31^{\circ} 1^{\prime} 43^{\prime \prime} \mathrm{N}, 61^{\circ} 30^{\prime} 4^{\prime \prime} \mathrm{E}$; Zahak: $30^{\circ} 53^{\prime} 38^{\prime \prime} \mathrm{N}$, $61^{\circ} 40^{\prime} 49^{\prime \prime} \mathrm{E}$; Bonjar: $31^{\circ} 2^{\prime} 34^{\prime \prime} \mathrm{N}, 61^{\circ} 34^{\prime} 6^{\prime \prime} \mathrm{E}$; Dust Mohammad: $31^{\circ} 8^{\prime} 41^{\prime \prime} \mathrm{N}, 61^{\circ} 47^{\prime} 33^{\prime \prime} \mathrm{E}$; Elevation above sea level $=483 \mathrm{~m}$ ). Seeds of the collected plants were separated for essential oil extraction. The essential oil extracted from dried samples by hydro distillation with a Clevenger apparatus for $4 \mathrm{~h}$ at $100{ }^{\circ} \mathrm{C}$. The water of obtained sample was taken by sodium sulfate. The extracted oil was transferred into microtubes $(1.5 \mathrm{ml})$ covered with aluminum foil and kept at $4{ }^{\circ} \mathrm{C}$ until use (Negahban et al., 2007). a-pinene (Sigma-Aldrich, P45680) (98\%) was purchased from Sigma-Aldrich (Madrid-Spain).

\subsection{INSECT REARING}

A colony of E. kuehniella was provided from the infected wheat flour in Zabol (Iran, $31^{\circ} 1^{\prime} 43^{\prime \prime} \mathrm{N}$, $61^{\circ} 30^{\prime} 4^{\prime \prime} \mathrm{E}$ ). The larvae were fed on an artificial diet containing wheat flour $(43 \mathrm{~g})$, yeast $(6 \mathrm{~g})$ and glycerine $(20 \mathrm{ml})$ in plastic containers $(17 \times 9 \times 5 \mathrm{~cm})$ under standard conditions of $25 \pm 1{ }^{\circ} \mathrm{C}, 70 \%$ relative humidity (R.H.) and 16L:8D of photoperiod (Lima et al., 2001) for at least three generations to get a homologous cohort.

\subsection{SAMPLE PREPARATION OF LARVAE TREAT- ED WITH TP EO AND A-PINENE}

Three artificial diets containing $\mathrm{LC}_{50}$ values of $T p$ EO $\left(4.91 \mu \mathrm{l} \mathrm{ml}^{-1}\right), \mathrm{LC}_{50}$ values of $\alpha$-pinene $\left(10.66 \mu \mathrm{l} \mathrm{ml}^{-1}\right)$ and untreated (as control) were provided. Ninety larvae in each diet starved for $6 \mathrm{~h}$, and then were allowed to feed on the diets for $24 \mathrm{~h}, 48 \mathrm{~h}$, and $72 \mathrm{~h}$. Thirty of fourth instar larvae (for each time interval) were randomly selected and their hemolymph was collected as described 
by Azambuja et al. (1991) and centrifuged at $20000 \mathrm{rpm}$ for 20 min at $4{ }^{\circ} \mathrm{C}$.

\subsection{DETERMINATION OF ESTERASE ACTIVITY (EC 3.1.1)}

The activity of esterase (EST) was measured as described by Han et al. (1998). Twenty microliters of $\alpha$-naphthyl acetate or $\beta$-naphthyl acetate $(10 \mathrm{mM})$, as substrates and $50 \mu \mathrm{l}$ of fast blue RR salt $(1 \mathrm{mM})$ were added to each tube. Then, the reaction was initiated by addition of $5 \mu \mathrm{l}$ of enzyme solution. The incubation was prolonged for 5 min and OD was recorded at $450 \mathrm{~nm}$ using microplate reader (Awareness: Statfax: 2100; USA). The produced and read substances for EST were $\alpha$-naphthyl acetate or $\beta$-naphthyl acetate.

\subsection{DETERMINATION OF GLUTATHIONE S- TRANSFERASE ACTIVITY (2.5.1.18)}

To assay the activity of glutathione $S$-transferase (GST) as $\mathrm{U} \mathrm{mg}^{-1}$ protein, twenty microliters of 1-chloro-2,4-dinitrobenzene (CDNB) $(20 \mathrm{mM})$ and 1,2-dichloro-4-nitrobenzene (DCNB) (40 mM, separately for each test) were separately pipetted into the microplate wells prior to adding $10 \mathrm{ml}$ of enzyme solution (Oppenorth et al., 1979). The incubation was prolonged for $5 \mathrm{~min}$ and OD was recorded at $340 \mathrm{~nm}$ (microplate reader Awareness: Statfax: 2100; USA). The produced and read substances were CDNB or DCNB.

\subsection{ASSAY OF ALANINE (EC 2.6.1.1) AND ASPAR- TATE (EC 2.6.1.1) AMINOTRANSFERASES}

A chlorometric assay using 2,4-dinitrophenyl hydrazine was used to assay alanine aminotransferase (ALT) and aspartate aminotransferase (AST) activities as $\mathrm{U} \mathrm{mg}^{-1}$ protein (Thomas, 1998). Reagent A (for AST) and reagent B (for ALT) were incubated separately with reagent D. After 5 minutes, $10 \mu \mathrm{l}$ of the enzyme solution was added and incubation continued for $60 \mathrm{~min}$. Finally, reagent $\mathrm{C}$ was added and absorbance was read at $340 \mathrm{~nm}$ using Statfax microplate reader (As instruction, Biochem Co., Iran). The produced and read substance was 2,4-dinitrophenyl hydrazine.

\subsection{ASSAY OF $\Gamma$-GLUTAMYL TRANSFERASE (EC 2.3.2.2)}

The activity of $\gamma$-Glutamyl transferase ( $\gamma$-GT) as $\mathrm{U} \mathrm{mg}^{-1}$ protein was assayed based on a method described by Szasz (1979) using a commercial kit (ZiestChem Diagnostic Co., Tehran-Iran). Ten microliters of enzyme solution were incubated with $50 \mu \mathrm{l}$ buffer reagent and $20 \mu \mathrm{l}$ of substrate reagent (L-g-glutamyl-3-carboxy-4-nitroanilide). After incubation of $3 \mathrm{~min}$, the absorbance was read at $405 \mathrm{~nm}$ (microplate reader Awareness: Statfax: 2100; USA). The produced and read substance was L- $\gamma$-glutamyl-3-carboxy-4-nitrianilide.

\subsection{ASSAY OF ALDOLASE (4.1.2.13)}

The method described by Pinto et al. (1969) was used to measure aldolase activity as $\mathrm{U} \mathrm{mg}^{-1}$ protein. The reaction mixture contained $50 \mu \mathrm{l}$ of buffer reagent, $25 \mu \mathrm{l}$ of substrate reagent (Fructose-1,6 di-phosphate), $10 \mu \mathrm{l}$ of cofactor reagent (NADH) and $20 \mu \mathrm{l}$ of enzyme solution (ZiestChem Diagnostics Co., Tehran-Iran). This mixture was incubated for $5 \mathrm{~min}$, and its absorbance was read at $340 \mathrm{~nm}$ (microplate reader Awareness: Statfax: 2100; USA). The produced and read substance was fructose-1,6-diphosphate.

\subsection{ASSAY OF LACTATE DEHYDROGENASE (EC 1.1.1.27)}

King (1965) method was used to evaluate the activity of lactate dehydrogenase (LDH) as $\mathrm{U} \mathrm{mg}^{-1}$ protein. To standardize volumes, $0.2 \mathrm{ml} \mathrm{NAD}{ }^{+}$solution was added to the test tubes and $0.2 \mathrm{ml}$ of water was added to control test tubes, each tube containing $1 \mathrm{ml}$ of the buffered substrate and $0.01 \mathrm{ml}$ of the sample was also added to the test tubes. Test tube samples were incubated for exactly $15 \mathrm{~min}$ at $37^{\circ} \mathrm{C}$ and then arrested by adding $1 \mathrm{~mL}$ of color reagent (2,4-dinitrophenyl hydrazine) to each tube and the incubation continued for an additional 15 $\mathrm{min}$. Then, the contents were cooled to room temperature, then $10 \mathrm{ml}$ of $0.4 \mathrm{~N} \mathrm{NaOH}$ was added to each tube to make the solutions strongly alkaline. Exactly $60 \mathrm{~s}$ after the addition of alkali to each tube, the intensity of color was measured at $340 \mathrm{~nm}$ (microplate reader Awareness: Statfax: 2100; USA). Specific activity was calculated by dividing absorbance with protein content in hemolymph.

\subsection{ASSAY OF ACID (EC 3.1.3.2) AND ALKALINE (EC 3.1.3.1) PHOSPHATASE}

The method described by Bessey et al. (1946) was used to measure acid phosphatase (ACP) and alkaline phosphatase (ALP) activities as $\mathrm{U} \mathrm{mg}^{-1}$ protein. To assay $\mathrm{ACP}$ and ALP, $p$-nitrophenol phosphate in Tris- $\mathrm{HCl}$ as 
a substrate (pH 5 and $\mathrm{pH} 8$ for acid and alkaline phosphatase, respectively) and the enzyme solution was incubated $(30 \mathrm{~min})$. Alkali was added to stop the reaction and adjust the $\mathrm{pH}$ for the determination of the concentration of the product formed. Absorbance then was read at $405 \mathrm{~nm}$ (microplate reader Awareness: Statfax: 2100; USA).

\subsection{PHENOLOXIDASE ASSAY}

To assay phenoloxidase (PO) activity $\left(\mathrm{U} \mathrm{mg}^{-1}\right.$ protein), the hemolymph of larvae was mixed with phosphate buffer $(\mathrm{pH} 7)$ and immediately centrifuged at $20000 \mathrm{~g}$ for $5 \mathrm{~min}$. The supernatant was discarded and the pellet was washed gently twice with phosphate buffer (Leonard et al., 1985). Cells were homogenized in $500 \mu \mathrm{l}$ of phosphate buffer centrifuged at $20000 \mathrm{~g}$ for $15 \mathrm{~min}$ to get the hemocyte lysate supernatant for PO assays. Samples were pre-incubated with phosphate buffer at $30{ }^{\circ} \mathrm{C}$ for $30 \mathrm{~min}$ before adding $50 \mu \mathrm{l}$ of $10 \mathrm{mM}$ aqueous solution of L-dihydroxyphenylalanine. The mixture was incubated for $5 \mathrm{~min}$ at $30{ }^{\circ} \mathrm{C}$ prior to measure the absorbance $490 \mathrm{~nm}$ (microplate reader Awareness: Statfax: 2100; USA). One unit of PO activity represents the amount of enzyme required to produce an increase in absorbance of $0.01 \mathrm{~min}^{-1}$ (Dularay \& Lackie, 1985).

\subsection{STATISTICAL ANALYSIS}

All data were compared by one-way analysis of variance (ANOVA) followed by Tukey's test. Differences
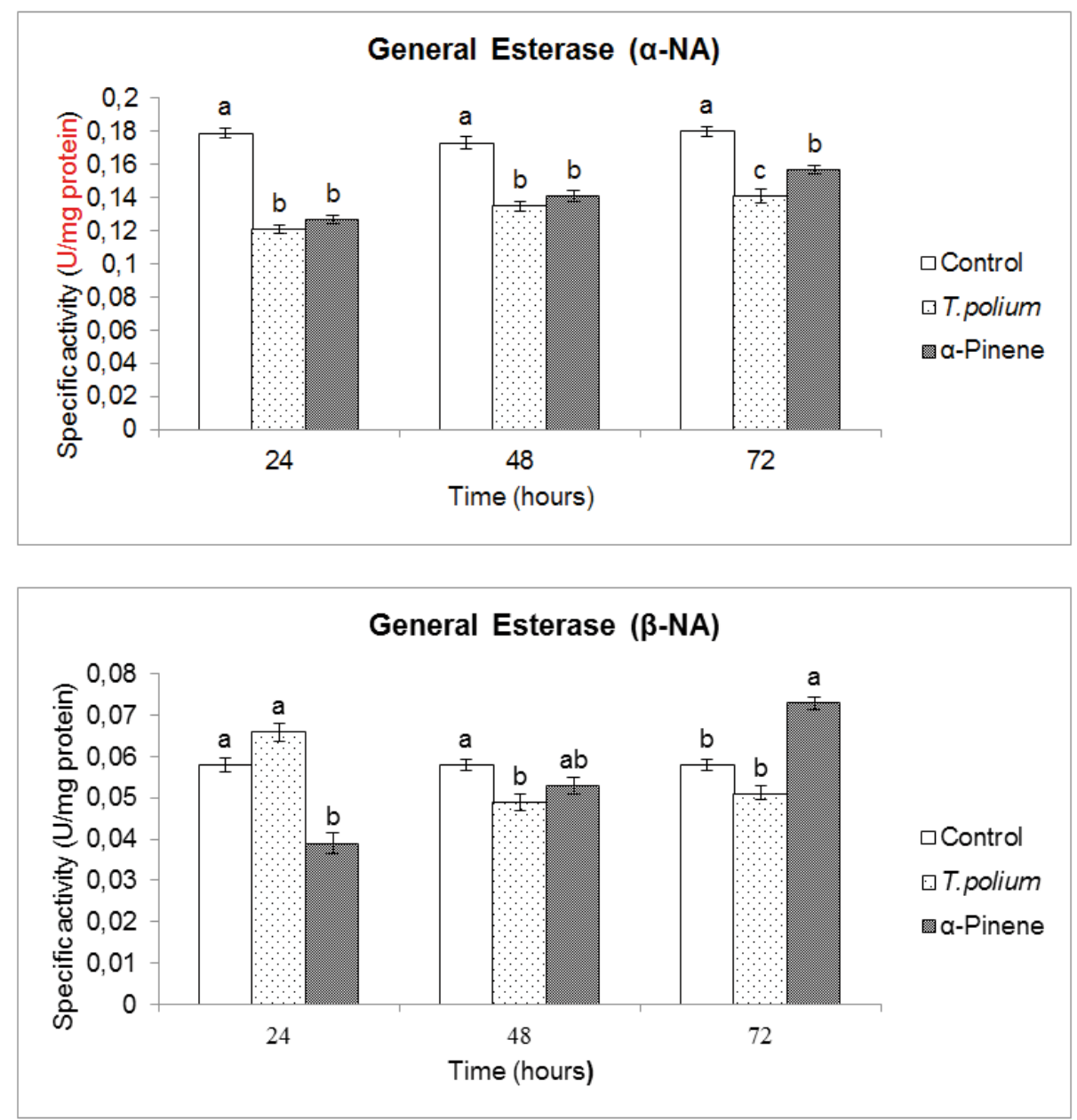

Figure 1: Effects of essential oil of T. polium and a-pinene on general esterase activity in the fourth instar larvae of E. kuehniella. Statistical differences have been done within each time intervals and marked by different letters (Tukey test, $p<0.05$ ). 
between samples were statistically considered at a probability less than $5 \%$ and marked in tables.

\section{RESULTS AND DISCUSSION}

Activity of EST measured by a-naphthyl acetate in the treated larvae by $\mathrm{Tp} \mathrm{EO}$ and $\alpha$-pinene was lower than control for all time intervals while the enzymatic activity were lower only after 24 and $48 \mathrm{~h}$ of post treatment when $\beta$-naphthyl acetate was used as substrate (Figure 1). After $72 \mathrm{~h}$ of post treatment, no statistical differences were observed between treated larvae by $\mathrm{T} p \mathrm{EO}, \alpha$-pinene and control (Figure 1). General esterases hydrolyzes ester bonds in xenobiotic compounds into acid and alcohol so any changes in their activities may contribute to chemical stress in insects (Ramsey et al., 2010). In the current study, activity of EST was significantly lower as compared to control highlighting its possible ineffectiveness to detoxify and to metabolize Tp EO and $\alpha$-pinene in the hemolyph of E. kuehniella larvae. Many researchers reported the lower activity of EST in different insects after exposure to botanical insecticides. For example, Nasr et al. (2015) found that Origanum vulgare L. EO caused lower activity of EST in the larvae of Plutella xylostella (L., 1758),Lep.: Pyralidae). Also, ingestion of Carum copticum L. EO and thymol by P. xylustella led to lower activity of EST in comparison with control larvae (Shahriari et al., 2017b). Mukanganyama et al. (2003) reported that adults of Rhopalosiphum padi (L., 1758), (Hem.: Aphididae) when fed on DIMBOA showed a lower EST activity.

Glutathione S-transferases (GSTs) are a family of multiple enzymes engaged in cellular detoxification of harmful chemical compounds e.g. herbicides, insecticides and chemical carcinogens (Enayati et al., 2005; Masella et al., 2005). In the current study, the activity of GST by using $\mathrm{CDNB}$ and $\mathrm{DCNB}$ significantly increased in the larvae treated by $T p \mathrm{EO}$ and $\alpha$-pinene in comparison
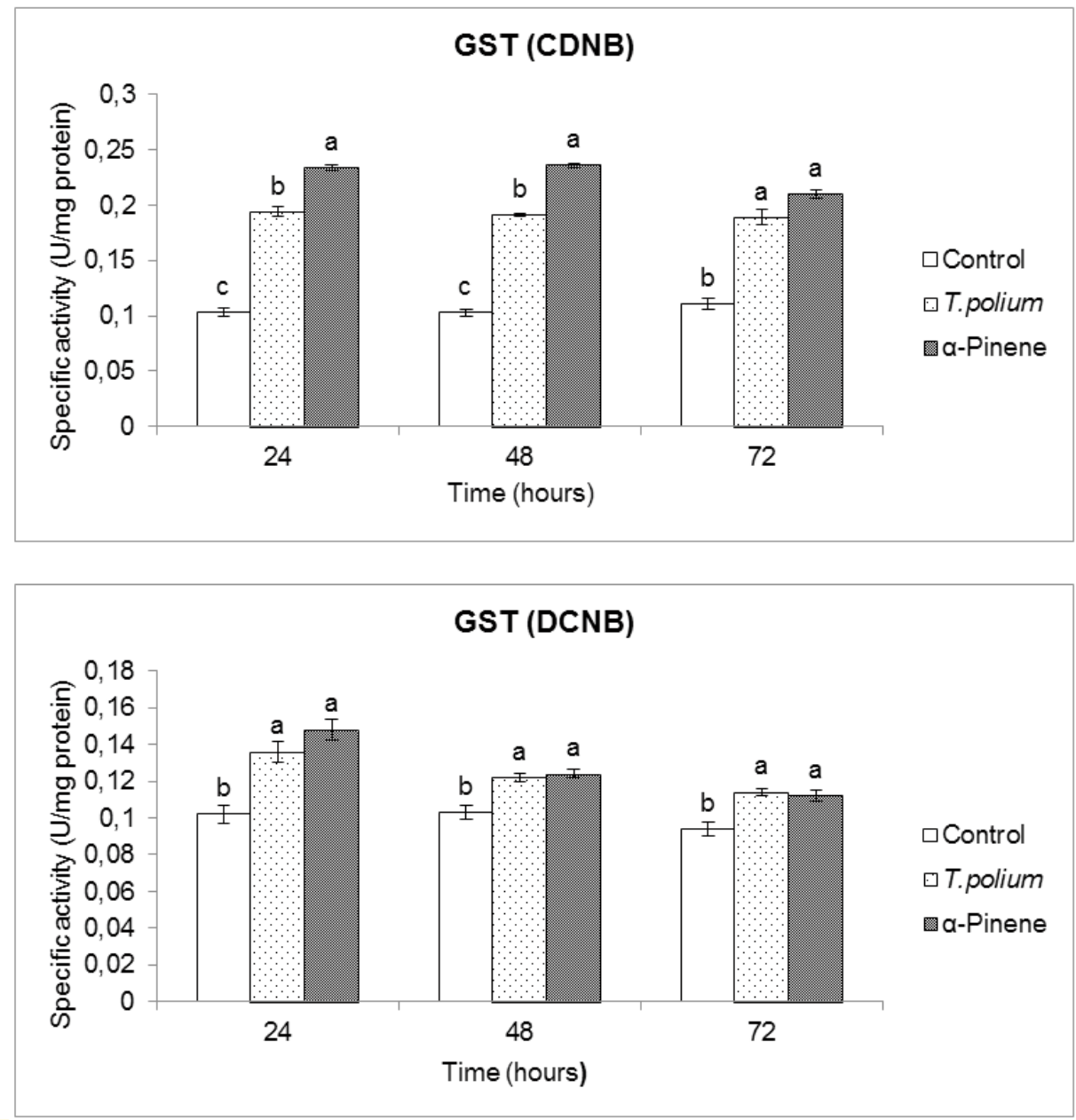

Figure 2: Effects of essential oil of T. polium and a-pinene on glutathion $s$ transferase activity in the fourth instar larvae of $E$. $k u e-$ hniella. Statistical differences have been done within each time intervals and marked by different letters (Tukey test, $p<0.05$ ). 
with control for all time intervals (Figure 2). These results indicate its importance to detoxify $\mathrm{Tp} \mathrm{EO}$ and $\alpha$-pinene in the hemolymph E. kuehniella larvae which has been shown in previous studies. Kumrungsee et al. (2014) reported higher activity of GST in the larvae of P. xylostella treated by thymol and 1,8-cineole. Yazdani et al. (2013) demonstrated enhanced activity of GST in the larvae of Glyphodes pyloalis Walker, 1859 (Lep.: Pyralidae) treated by $\mathrm{LC}_{10}, \mathrm{LC}_{30}$ and $\mathrm{LC}_{50}$ concentrations of Lavandula angustifolia Mill EO. Also, Shahriari et al. (2017b) showed
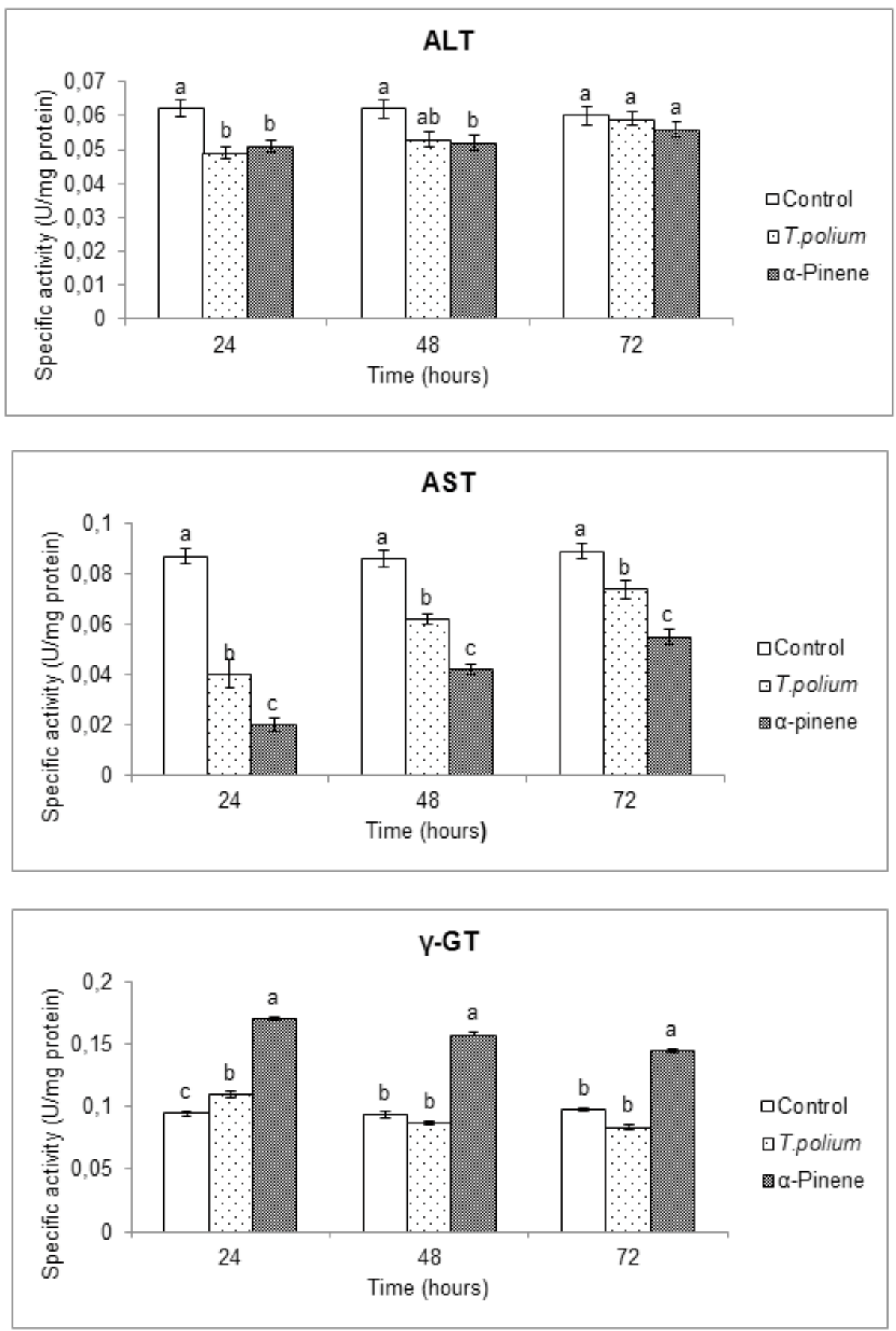

Figure 3: Effects of essential oil of T. polium and a-pinene on amino transferase activities in the fourth instar larvae of E. kuehniella. Statistical differences have been done within each time intervals and marked by different letters (Tukey test, $p<0.05$ ). 
higher activity of GST in larvae of E. kuehniella fed on diets containing the $\mathrm{LC}_{50}$ concentration of Ajwain and thymol oils.

The larvae treated by Tp EO and $\alpha$-pinene showed the lower activity of ALT than control after $24 \mathrm{~h}$ for Tp $\mathrm{EO}$ as well as 24 and $48 \mathrm{~h}$ for a-pinene (Figure 3). Also, the activity of AST significantly decreased in the larvae treated by Tp EO and $\alpha$-pinene than control for all intervals which is more obvious in case of $\alpha$-pinene (Figure 3). $\gamma$-GT showed the higher activity in the larvae treated by Tp EO and $\alpha$-pinene after $24 \mathrm{~h}$ of post treatment (Figure 3). Alanine amino transferase is an important transaminase in fat bodies and hemolyph of insects that has a key role in proline metabolism (Thomas, 1998). Aspartate amino transferase, a transaminase similar to ALT, involves in amino acid metabolism to catalyze the reversible transfer of $\alpha$-amino group and $\alpha$-keto acid (such as between aspartate and glutamate) during the Krebs cycle (Klowden 2007). Also, Shahriari \& Sahebzadeh (2017) reported that activity of ALT decreased by diallyl disulfide treatment on E. kuehniella after $24 \mathrm{~h}$ which indicated non-involvement of proline in supplying energy for larvae of E. kuehniella. In addition, Shahriari et al. (2017b) demonstrated that the diet containing LC $_{50}$ concentration of Carum copticum L. EO and thymol significantly decreased activities of ALT and AST in E. kuehniella. Such findings may refer to the low amounts of oxaloacetate to be transferred into Krebs cycle. Our results showed that activity of $\gamma$-GT increased in the treated larvae by $T p \mathrm{EO}$ and $\alpha$-pinene. In transamination cycle of insects, $\gamma$-glutamyl transferase $(\gamma-\mathrm{GT})$ plays an important role in synthesizing glutathione and detoxifying xenobiotic compounds (Ramzi et al., 2014). Increased activity of $\gamma$-GT following treatments by EOs can be due to
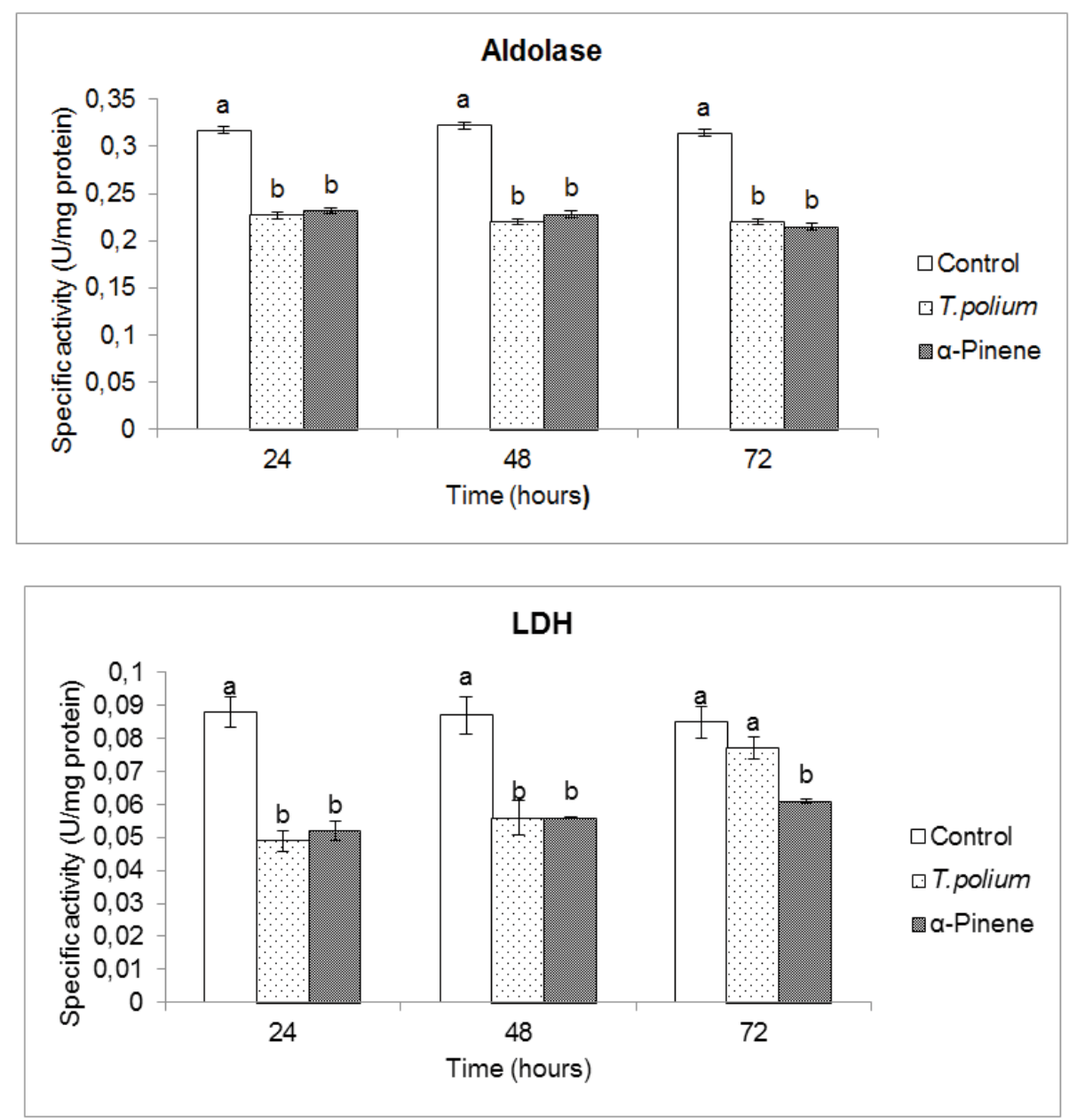

Figure 4: Effects of essential oil of T. polium and a-pinene on aldolase and lactate dehydrogenase (LDH) activities in the fourth instar larvae of E. kuehniella. Statistical differences have been done within each time intervals and marked by different letters (Tukey test, $p<0.05)$. 
removal of these compounds in the hemolymph of larvae as other reports (Ramzi et al., 2014; Shahriari \& Sahebzadeh, 2017; Shahriari et al., 2017b).

Larval treatment by the $\mathrm{LC}_{50}$ concentration of $\mathrm{TP}$ EO and $\alpha$-pinene caused to lower the activities of aldolase and LDH for all time intervals (Figure 4). Aldolase and $\mathrm{LDH}$ are the important glycolytic enzymes which involve in carbohydrate metabolism. In the initial steps of glycolysis, aldolase catalyzes glycogen into energy production (Pinto et al., 1969) while LDH is involved in the production of energy by conversion of pyruvate to lactate and back. Also, LDH has been used as an indicative criterion of exposure to chemical stress (Senthil-Nathan, 2006). In our study, Tp EO and a-pinene mitigated activity of glycolysis so the lower amounts of pyruvate were entered into Krebs cycle to be processed in energy production. Earlier studies showed the negative effects of plant alle- lochemicals on aldolase and LDH activities of different pests. Shahriari et al. (2017b) reported that C. copticum EO and thymol led to the lower activities of aldolase and LDH in the E. kuehniella. Citrullus colocynthis (L.) Schrad agglutinin caused significantly lower activity of aldolase in the fourth instar larvae of Ectomyelois ceratoniae (Zeller, 1839) (Lep.: Pyralidae) after 48 h of post-treatment (Ramzi et al., 2014). In addition, Selin-Rani et al. (2016) demonstrated that methanol extract of Alangium salvifolium (L.f.) Wangerin caused lower activity of LDH in the larvae of Spodoptera litura (F., 1775) (Lep.: Noctuidae).

Two hydrolytic enzymes ACP and ALP play the crucial roles in the lipid digestion and dephosphorylation of phosphate groups in different tissues of insects (Klowden, 2007). In case of our study, activity of ACP significantly increased (Figure 5) while the activity of ALP significantly decreased in the treated larvae by Tp EO
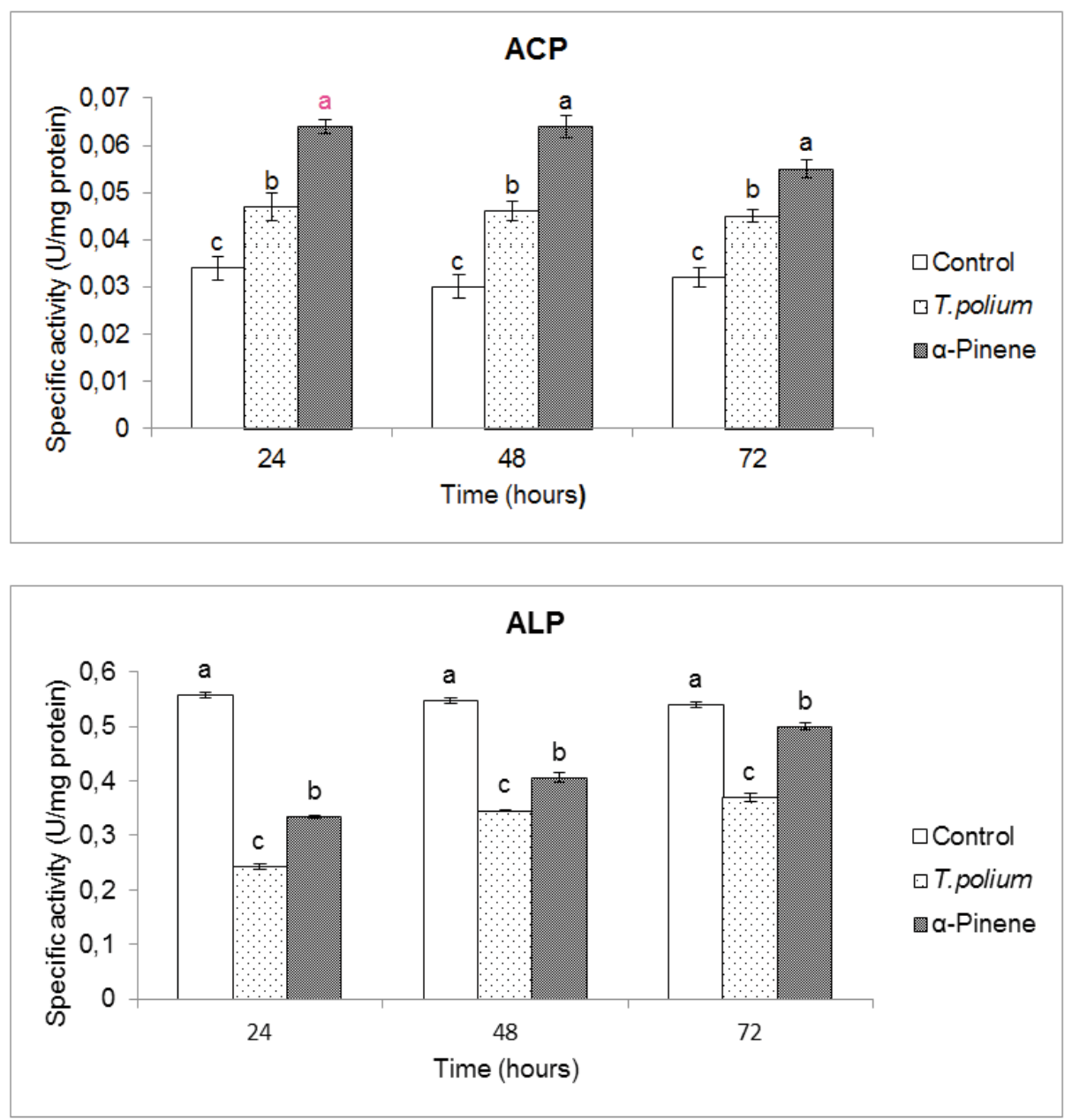

Figure 5: Effects of essential oil of T. polium and a-pinene on acid phosphatase (ACP) and alkaline phosphatase (ALP) activities in the fourth instar larvae of E. kuehniella. Statistical differences have been done within each time intervals and marked by different letters (Tukey test, $p<0.05$ ). 


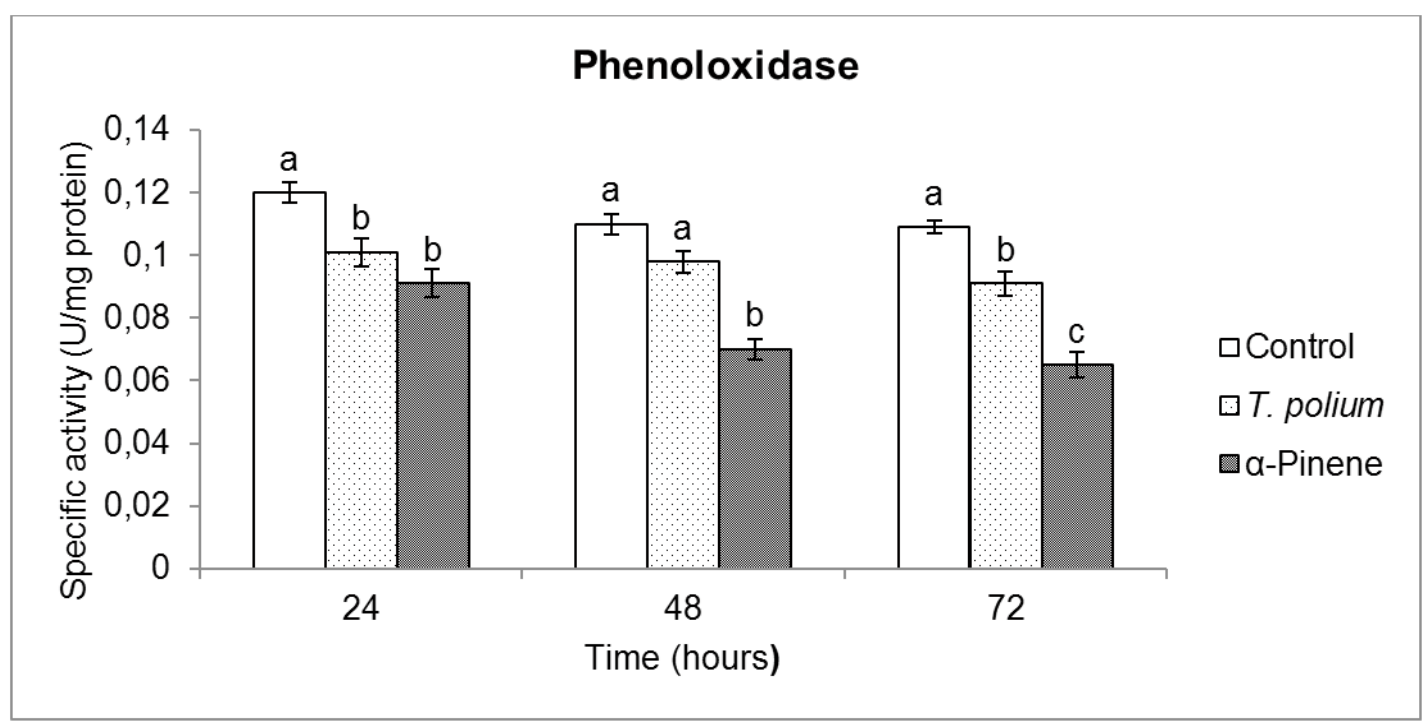

Figure 6: Effects of essential oil of T. polium and a-pinene on phenoloxidase activity (PO) in the fourth instar larvae of E. kuehniella. Statistical differences have been done within each time intervals and marked by different letters (Tukey test, $p<0.05$ ).

and $\alpha$-pinene for all time intervals (Figure 5). Similar results have been observed in E. kuehniella upon treatment with diallyl disulfide (Shahriari \& Sahebzadeh, 2017). Previous studies on Eurygaster integriceps Puton, 1881, (Hem.: Scutelleridae), Pieris rapae (L., 1758), (Lep.: Pieridae), Xanthogaleruca luteola (Muller, 1766) (Col.: Chrysomelidae) and Helicoverpa armigera (Hübner, (1808)) (Lep.: Noctuidae) have shown similar changes in phosphatases activities after treatments by botanical pesticides (Senthil-Nathan, 2006; Zibaee \& Bandani, 2010; Hasheminia et al., 2011; Mojarab-Mahboubkar \& Sendi, 2016). The higher activity of phosphatase suggests potential involvement in the detoxification and metabolize of toxic compounds (Hasheminia et al., 2011; Shahriari et al., 2017b) so that any decrease in phosphatase activities of treated larvae with botanical insecticides may refer to changes in physiological balance in the midgut of insects causing lower dephosphorylation of phosphate groups for energy production (Senthil-Nathan, 2006; Ramzi et al., 2014; Shahriari \& Sahebzadeh, 2017).

The phenoloxidase activity was significantly lower in larvae treated by $T p$ EO and $\alpha$-pinene than control (Figure 6). Phenoloxidase (PO) is an important enzyme in cellular and humoral immunity of invertebrates. This enzyme also performed important functions in insect development and physiological processes such as catalyzing the synthesis of cytotoxic quinones, eliminate attacking infective agents, melanization of capsule, sclerotization, tanning of cuticle and wound healing in insects (Nappi \& Christensen, 2005; Kanost \& Gorman, 2008). Zibaee \& Bandani (2010b) demon- strated that methanolic extract of Artemisia annua L. decreased PO activity E. integriceps adults. However, Mojarab-Mahboubkar \& Sendi (2016) reported the higher activity of $\mathrm{PO}$ in the treated larvae of $\mathrm{H}$. armigera with the $\mathrm{LC}_{50}$ concentration of methanolic extract of A. annua.

\section{CONCLUSION}

Many derivatives of plants which are applied in plant protection are known to affect biological and physiological functions of insects. Our results demonstrated that $T p$ EO and $\alpha$-pinene decreased all enzymes involved in intermediary metabolism of E. kuehniella, even phenoloxidase, which is a critical enzyme in immunity against entomopathogenic agents. In contrast, the compounds led to the increased activities of GST, $\gamma$-GT, and ACP, which is involved in removing xenobiotic compounds from insects. These disturbances in addition to our previous study on impairing digestion and survival may highlight appropriate direct and indirect effects of Tp EO and a-pinene on E. kuehniella larvae as a potential botanical insecticide. Our results confirmed that the time of treatment application effectively caused significant or non-significant differences between enzymatic activities after treatment with the Tp EO and $\alpha$-pinene treatments. As a conclusion, the findings of this study confirmed that due to conduct a potential and low-cost method for E. kuehniella management, Tp EO as well as its pure component " $\alpha$-pinene" effectively could control the economic 
damage of this pest in the stores. This conclusion raised because of showing no significant differences between enzymatic activates after treating the larvae with either Tp EO or a-pinene.

\section{ACKNOWLEDGMENTS}

This research was supported by University of Zabol and University of Guilan.

\section{REFERENCES}

Azambuja, P. D., Garcia, E. S., \& Ratcliffe, N.A. (1991). Aspects of classification of Hemiptera hemocytes from six triatomine species. Memorias do Instituto Oswaldo Cruz, 86(1), 1-10. https://doi.org/10.1590/S0074-02761991000100002

Bessey, O. A. (1946). A method for a rapid determination of alkaline phosphatase with five cubic millimeters of serum. Journal of Biological Chemistry, 207, 19-23.

Bohinc, T., Horvat, A., Andrić, G., Golić, M. P., Kljajić, P., \& Trdan, S. (2018). Comparison of three different wood ashes and diatomaceous earth in controlling the maize weevil under laboratory conditions. Journal of Stored Products Research, 79, 1-8. https://doi.org/10.1016/j.jspr.2018.06.007

Bohinc, T., Vayias, B., Bartol, T., \& Trdan, S. (2013). Assessment of insecticidal efficacy of diatomaceous earth and powders of common lavender and field horsetail against bean weevil adults. Neotropical Entomology, 42(6), 642-648. https://doi. org/10.1007/s13744-013-0168-7

Bouayad, N., Rharrabe, K., Lamhamdi, M., Nourouti, N. G., \& Sayah, F. (2012). Dietary effects of harmine, a $\beta$-carboline alkaloid, on development, energy reserves and $\alpha$-amylase activity of Plodia interpunctella Hübner (Lepidoptera: Pyralidae). Saudi Journal of Biological Sciences, 19(1), 7380. https://doi.org/10.1016/j.sjbs.2010.12.004

Darabpour, E., Motamedi, H., \& Nejad, S. M. S. (2010). Antimicrobial properties of Teucrium polium against some clinical pathogens. Asian Pacific Journal of Tropical Medicine, 3(2), 124-127. https://doi.org/10.1016/S1995-7645(10)60050-8

Dularay, B., \& Lackie, A. M. (1985). Haemocytic encapsulation and the prophenoloxidase activation pathway in the locust Schistocerca gregaria. Journal of Insect Biochemistry, 15(6), 827-834. https://doi.org/10.1016/0020-1790(85)90112-X

Enayati, A. A., Ranson, H., \& Hemingway, J. (2005). Insect glutathione transferases and insecticide resistance. Insect Molecular Biology, 14(1), 3-8. https://doi.org/10.1111/j.13652583.2004.00529.x

Han, Z., Moores, G. D., Denholm, I., \& Devonshire, A. L. (1998). Association between Biochemical Markers and Insecticide Resistance in the Cotton Aphid, Aphis gossypii Glover. Pesticide Biochemistry and Physiology, 62(3), 164171. https://doi.org/10.1006/pest.1998.2373

Hasheminia, S. M., Sendi, J. J., Jahromi, K. T., \& Moharramipour, S. (2011). The effects of Artemisia annua L. and Achillea millefolium L. crude leaf extracts on the toxicity, devel- opment, feeding efficiency and chemical activities of small cabbage Pieris rapae L.(Lepidoptera: Pieridae). Pesticide Biochemistry and Physiology, 99(3), 244-249. https://doi. org/10.1016/j.pestbp.2010.12.009

Heydarzade, A., \& Moravvej, G. (2012). Contact toxicity and persistence of essential oils from Foeniculum vulgare, Teucrium polium and Satureja hortensis against Callosobruchus maculatus (Fabricius) (Coleoptera: Bruchidae) adults. Turkish Journal of Entomology, 36, 507-518.

Isman, M. B. (2006). Botanical insecticides, deterrents, and repellents in modern agriculture and an increasingly regulated world. Annual Review of Entomology, 51, 45-66. https:// doi.org/10.1146/annurev.ento.51.110104.151146

Kanost, M. R., \& Gorman, M. J. (2008). Phenoloxidases in Insect Immunity. N.E. Beckage (Eds.), Insect Immunology, (pp. 69-96). San Diego: Academic press. https://doi. org/10.1016/B978-012373976-6.50006-9

Kim, S. W., Kang, J., \& Park, I. K. (2013). Fumigant toxicity of Apiaceae essential oils and their constituents against Sitophilus oryzae and their acetylcholinesterase inhibitory activity. Journal of Asia-Pacific Entomology, 16(4), 443-448. https://doi.org/10.1016/j.aspen.2013.07.002

King, J. (1965). The dehydrogenases or oxidoreductases. Lactate dehydrogenase. In: J. King, (Eds.), Practical clinical enzymology (pp. 83-93). London: Van Nostrand D.

Klowden, M. J. (2007). Physiological Systems in Insects. Academic Press.

Kumrungsee, N., Pluempanupat, W., Koul, O., \& Bullangpoti, V. (2014). Toxicity of essential oil compounds against diamondback moth, Plutella xylostella, and their impact on detoxification enzyme activities. Journal of Pest Science, 87(4), 721-729. https://doi.org/10.1007/s10340-014-0602-6

Leonard, C., Söderhäll, K., \& Ratcliffe, N. A. (1985). Studies on prophenoloxidase and protease activity of Blaberus craniifer haemocytes. Journal of Insect Biochemistry, 15(6), 803810. https://doi.org/10.1016/0020-1790(85)90109-X

Lima Filho, M., Favero, S., \& Lima, J. O. G. D. (2001). Production of the Mediterranean flour moth, Anagasta kuehniella (Zeller) (Lepidoptera: Pyralidae), on an artificial diet containing corn meal. Neotropical Entomology, 30(1), 37-42. https://doi.org/10.1590/S1519-566X2001000100007

Lowry, O. H., Rosebrough, N. J., Farr, A. L., \& Randall, R. J. (1951). Protein measurement with the Folin phenol reagent. Journal of Biological Chemistry, 193(1), 265-275.

Masella, R., Di Benedetto, R., Varì, R., Filesi, C., \& Giovannini, C. (2005). Novel mechanisms of natural antioxidant compounds in biological systems: involvement of glutathione and glutathione-related enzymes. The Journal of Nutritional Biochemistry, 16(10), 577-586. https://doi.org/10.1016/j. jnutbio.2005.05.013

Mojarab-Mahboubkar, M., \& Jalali Sendi, J. (2016). Chemical composition, insecticidal and physiological effect of methanol extract of sweet wormwood (Artemisia annua L.) on Helicoverpa armigera (Hübner) (Lepidoptera: Noctuidae). Toxin Reviews, 35(3-4), 106-115. https://doi.org/10.1080/1 5569543.2016.1203336

Moghtader, M. (2009). Chemical composition of the essential oil of Teucrium polium L. from Iran. American-Eurasian 
Journal of Agricultural and Environmental Science, 5(6), 843846.

Mukanganyama, S., Figueroa, C. C., Hasler, J. A., \& Niemeyer, H. M. (2003). Effects of DIMBOA on detoxification enzymes of the aphid Rhopalosiphum padi (Homoptera: Aphididae). Journal of Insect Physiology, 49(3), 223-229. https://doi. org/10.1016/S0022-1910(02)00269-X

Nappi, A. J., \& Christensen, B. M. (2005). Melanogenesis and associated cytotoxic reactions: applications to insect innate immunity. Insect Biochemistry and Molecular Biology, 35(5), 443-459. https://doi.org/10.1016/j.ibmb.2005.01.014

Nasr, M., Sendi, J. J., Moharramipour, S., \& Zibaee, A. (2017). Evaluation of Origanum vulgare L. essential oil as a source of toxicant and an inhibitor of physiological parameters in diamondback moth, Plutella xylustella L.(Lepidoptera: Pyralidae). Journal of the Saudi Society of Agricultural Sciences, 16(2), 184-190. https://doi.org/10.1016/j.jssas.2015.06.002

Negahban, M., Moharramipour, S., \& Sefidkon, F. (2007). Fumigant toxicity of essential oil from Artemisia sieberi Besser against three stored-product insects. Journal of Stored Products Research, 43(2), 123-128. https://doi.org/10.1016/j. jspr.2006.02.002

Oppenoorth, F. J., Van der Pas, L. J. T., \& Houx, N. W. H. (1979). Glutathione S-transferase and hydrolytic activity in a tetrachlorvinphos-resistant strain of housefly and their influence on resistance. Pesticide Biochemistry and Physiology, 11(1-3), 176-188. https://doi.org/10.1016/0048-3575(79)90057-9

Pinto, P. V., Van Dreal, P. A., \& Kaplan, A. (1969). Aldolase: I. colorimetric determination. Clinical Chemistry, 15(5), 339-348.

Rajendran, S., \& Sriranjini, V. (2008). Plant products as fumigants for stored-product insect control. Journal of Stored Products Research, 44(2), 126-135. https://doi.org/10.1016/j. jspr.2007.08.003

Ramsey, J. S., Rider, D. S., Walsh, T. K., De Vos, M., Gordon, K. H. J., Ponnala, L., ... \& Jander, G. (2010). Comparative analysis of detoxification enzymes in Acyrthosiphon pisum and Myzus persicae. Insect Molecular Biology, 19, 155-164. https://doi.org/10.1111/j.1365-2583.2009.00973.x. https://doi. org/10.1111/j.1365-2583.2009.00973.x

Ramzi, S., Sahragard, A., \& Zibaee, A. (2014). Effects of Citrullus colocynthis agglutinin on intermediary metabolism of Ectomyelois ceratoniae Zeller (Lepidoptera: Pyralidae). Journal of Asia-Pacific Entomology, 17(3), 273-279. https://doi. org/10.1016/j.aspen.2014.01.005

Selin-Rani, S., Senthil-Nathan, S., Revathi, K., Chandrasekaran, R., Thanigaivel, A., Vasantha-Srinivasan, P., ... \& Pradeepa, V. (2016). Toxicity of Alangium salvifolium Wang chemical constituents against the tobacco cutworm Spodoptera litura Fab. Pesticide Biochemistry and Physiology, 126, 92-101. https:// doi.org/10.1016/j.pestbp.2015.08.003

Nathan, S. S. (2006). Effects of Melia azedarach on nutritional physiology and enzyme activities of the rice leaffolder Cnaphalocrocis medinalis (Guenée) (Lepidoptera: Pyralidae). Pesticide Biochemistry and Physiology, 84(2), 98-108. https:// doi.org/10.1016/j.pestbp.2005.05.006

Seo, S. M., Kim, J., Kang, J., Koh, S. H., Ahn, Y. J., Kang, K. S., \& Park, I. K. (2014). Fumigant toxicity and acetylcholinesterase inhibitory activity of 4 Asteraceae plant essential oils and their constituents against Japanese termite (Reticulitermes speratus Kolbe). Pesticide Biochemistry and Physiology, 113, 55-61. https://doi.org/10.1016/j.pestbp.2014.06.001

Shahriari, M., \& Sahebzadeh, N. (2017). Effect of diallyl disulfide on physiological performance of Ephestia kuehniella Zeller (Lepidoptera: Pyralidae). Archives of Phytopathology and Plant Protection, 50(1-2), 33-46. https://doi.org/10.1080/032 35408.2016.1253252

Shahriari, M., Sahebzadeh, N., Sarabandi, M., \& Zibaee, A. (2016). Oral Toxicity of Thymol, a-Pinene, Diallyl Disulfide and Trans-Anethole, and Their Binary Mixtures against Tribolium castaneum Herbst Larvae (Coleoptera: Tenebrionidae). Jordan Journal of Biological Sciences, 9(3), 213-219.

Shahriari, M., Sahebzadeh, N., \& Zibaee, A. (2017). Effect of Teucrium polium (Lamiaceae) essential oil on digestive enzyme activities and energy reserves of Ephestia kuehniella (Lepidoptera: Pyralidae). Invertebrate Survival Journal, 14, 182-189.

Shahriari, M., Sahbzadeh, N., Zibaee, A., Khani, A., \& SenthilNathan, S. (2017b). Metabolic response of Ephestia kuehniella Zeller (Lepidoptera: Pyralidae) to essential oil of Ajwain and thymol. Toxin Reviews, 36(3), 204-209. https://doi.org/1 0.1080/15569543.2017.1294605

Sharififar, F., Dehghn-Nudeh, G., \& Mirtajaldini, M. (2009). Major flavonoids with antioxidant activity from Teucrium polium L. Food Chemistry, 112(4), 885-888. https://doi. org/10.1016/j.foodchem.2008.06.064

Szasz, G. (1979). Reaction-rate method for gamma-glutamyltransferase activity in serum. Clinical Chemistry, 22(12), 2051-2055.

Tariq, M., Ageel, A. M., Al-Yahya, M. A., Mossa, J. S., \& Al-Said, M. S. (1989). Anti-inflammatory activity of Teucrium polium. International Journal of Tissue Reactions, 11(4), 185-188.

Thomas, L. (1998). Alanine aminotransferase (ALT), Aspartate aminotransferase (AST). Clinical Laboratory Diagnostics. 1st ed. Frankfurt: TH-Books Verlagsgesellschaft, 2, 55-65.

Yang, K., Wang, C. F., You, C. X., Geng, Z. F., Sun, R. Q., Guo, S. S., ... \& Deng, Z. W. (2014). Bioactivity of essential oil of Litsea cubeba from China and its main compounds against two stored product insects. Journal of Asia-Pacific Entomology, 17(3), 459-466. https://doi.org/10.1016/j.aspen.2014.03.011

Yazdani, E., Sendi, J. J., Aliakbar, A., \& Senthil-Nathan, S. (2013). Effect of Lavandula angustifolia essential oil against lesser mulberry pyralid Glyphodes pyloalis Walker (Lep: Pyralidae) and identification of its major derivatives. Pesticide Biochemistry and Physiology, 107(2), 250-257. https://doi. org/10.1016/j.pestbp.2013.08.002

Zibaee, A., \& Bandani, A. (2010). A study on the toxicity of a medicinal plant, Artemisia annua L. (Asteracea) extracts to the sunn pest, Eurygaster integriceps Puton (Hemiptera: Scutelleridae). Journal of Plant Protection Research, 50(1), 79-85. https://doi.org/10.2478/v10045-010-0014-4

Zibaee, A., \& Bandani, A. R. (2010b). Effects of Artemisia annua L. (Asteracea) on digestive enzymes profiles and cellular immune reactions of sun pest, Eurygaster integriceps (Heteroptera: Scutellaridae), against Beauvaria bassiana. Bulletin of Entomological Research, 100, 185-196. https://doi. org/10.1017/S0007485309990149 